RADOVI

Zavoda za znanstveni rad HAZU Varaždin

ANKA MIŠETIĆ

Arhitektonski fakultet - Studij dizajna, Zagreb

amisetic@arhitekt.hr
UDK 304:71(497.52)

Izvorni znanstveni članak Original Scientific Paper

Primljeno: 30.01.2017.

Prihvaćeno: 18. 10. 2017.

DOI: http://doi.org/10.21857/yl4okf7829

\title{
SOCIO-PROSTORNI ASPEKTI RAZVOJA SJEVEROZAPADNE HRVATSKE: IZMEĐU NORMIRANJA I PRAKSI
}

\begin{abstract}
Rad u središte stavlja pitanje koliko su vrijednosti socijalne i ekološke održivosti prepoznatljive u razvoju Sjeverozapadne Hrvatske kroz dvije usporedne analize. Proa je analiza županijskih prostornih planova koji su službeni dokumenti pet županija ovog prostora ili analiza normationog aspekta, a druga je analiza stavova lokalnog stanovništva o okolišnim pitanjima i o njihovoj participaciji u aktivnostima lokalne zajednice (Pilarov barometar hrvatskog društva, 2008. i 1014.). Rezultati su potvrdili usvojenost ekoloških kriterija, dok su važni socijalni kriteriji održivosti (participacija, informiranje, lokalna demokracija) izostali u planovima. Analiza stavova lokalnog stanovništva pokazala je da je ekološka dimenzija razvoja većinski prihvaćena, dok se socijalna dimenzija, mjerena angažmanom u lokalnoj zajednici tek razvija, ali nije zanemariva. Uočen je raskorak između stvarnosti u kojoj se stanovnici već uključuju u pitanja važna za razvoj zajednice i normativne sfere koja takve aktionosti ne anticipira u procedurama.
\end{abstract}

\section{UVOD}

Složenica socio-prostorni razvoj uvriježila se, poglavito u društvenim znanostima, kao koncept kojim se opisuju mnogostruke veze društva i prostora, načina života koji je definiran kulturom, vrijednostima, normama i običajima i prirodnog, fizičkog okruženja u kojem se društvo konstituira. Veze društva i prostora, prirode i kulture, bile su trajni poticaj za plodne rasprave u povijesti filozofije i znanosti. Za sociologiju, posebno je značajna Simmelova rasprava o razlici i komplementarnosti prirode i kulture u kojoj autor naglašava temeljnu razliku između dvije interpretacije, a zatim i dva odnosa što ga priroda i čovjek oblikuju spram svijeta koji nas okružuje. S jedne strane „suštinska ravnopravnost među stvarima“ koja odlikuje prirodu 
i koja se "temelji na jednakosti pred prirodnim zakonima“ susreće se s karakteristično ljudskom interpretacijom koja uključuje i „vrijednosni poredak“ na temelju kojega čovjek hijerarhizira životni okoliš temeljem vrijednosti koje pripisuje svemu oko sebe. Dok je priroda, posljedično, indiferentna u djelovanju, čovjek interpretira svijet i djeluje u njemu vrednujući ga i hijerarhizirajući u procesima kojima se, u odnosu na prirodu, kroz kulturu stvara jedan autonomni poredak. Može se reći da Simmelovo tumačenje daje općeniti okvir za interpretaciju socio-prostornih aspekata nekog fenomena. (Simmel, 2004.)

Stoga je važno naglasiti da govoreći o socio-prostornom razvoj u prvom redu govorimo o odnosu koji se gradi između kulture i prirode na jednom prostoru. U taj odnos kultura donosi vrijednosti, norme, običaje, simbole, ili najkraće rečeno način života. Priroda donosi ono što obično nazivamo resursima, donosi raznolikost životnih zajednica, specifične ritmove $i$, naravno, prirodne procese i zakone. Rezultat tog odnosa je jedna vrsta posebnog krajolika koji se u najširem smislu može nazvati kulturnim krajolikom, a uključuje različite krajolike, naselja i prirodne elemente nastale kao rezultat više ili manje usklađenog djelovanja čovjeka i prirode. Navedene tendencije idu u prilog zaključku da je prostor zadobio status posebne vrijednosti koja u sebi uključuje različite aspekte: ekološki, ambijentalni, ekonomski, socijalni, kulturni. Usporedo s tim, odgovornost za prostor i procese koji se u njemu odvijaju pripisuje se različitim akterima, među kojima sve važniju ulogu ima upravo lokalna zajednica (o tipologiji aktera u prostoru vidjeti više u: Seferagić, 2008.).

\section{VAŽNOST KONCEPTA EKOLOŠKE I SOCIJALNE ODRŽIVOSTI}

Općenito se može reći da je sociološki aspekt analize prostornog razvoja korisno započeti istražujući odnos između kulturnih vrijednosti i konkretnih rješenja i odluka koje se realiziraju u nekom prostoru. Pri tome se i u prostoru reprezentiraju zajednice, institucije i socijalni indentiteti kao prepoznatljivi društveni sudionici koji sudjeluju u procesima u svijetu života (Rogić, 2003.). "Regionalne posebnosti temeljene na prirodnim i društveno-razvojnim (...) osobinama, nositelj su vrijednosti i bogatstva nacije i moraju biti u potpunosti sagledane i postavljene kao osnova svih procesa planiranja." (Magaš, 2014.: 268).

Takav pristup kompatibilan je novim principima planiranja i novoj ulozi prostornog planera u suvremenom svijetu: “U odnosu na druge discipline, prostorno planiranje se ističe po svom osnovnom fokusu na interese društva u cjelini, naselja ili regije kao cjeline i na dugoročnu budućnost. Prostorni planeri se snažno obvezuju da će služiti općem interesu i lokalnoj dimenziji i štititi ih." (The Charter of European Planning, 2013.: 75). 
Suvremeni, postmoderni pristupi prostornom razvoju iznjedrili su dvije ključne vrijednosti, koje su ujedno prerasle $\mathrm{u}$ analitičke koncepte i kriterije za planiranje prostora. To su vrijednosti ekološke i socijalne održivosti. Koncept ekološke održivosti šire je elaboriran i prihvaćen a usmjerava se na zaštitu životnih uvjeta, životnih ciklusa i života u cjelini. S druge strane, socijalno održiva zajednica najopćenitije se definira kao pravedna, raznovrsna, povezana i demokratična, zajednica koja vodi računa o interakciji članova, socijalnim mrežama, specifičnosti duha mjesta, stabilnosti i sigurnost (Barron, Gauntlett, 2002.).

Koncept socijalne održivosti za lokalnu zajednicu podrazumijeva i mogućnost učenja i usavršavanja, a jedna od glavnih aktivnosti je implementacija participativnog procesa kako bi se omogućila dobra informiranost građana kao preduvjet za sudjelovanje u donošenju odluka ali i prepoznale ljudske potrebe, aspiracije i vrijednosti (Baker, Coaffee, Sherriff, 2007.; Doak, Parker, 2005.).

Istraživanje socijalne održivosti suočava se više različitih pitanja, među kojima treba istaknuti: Kakva je uloga urbane lokalne zajednice u svim fazama socioprostornog razvoja, od planiranja do realizacije? Odgovor na ovo pitanje vodi do građanske participacije kao temeljnog procesa u ostvarivanju socijalno održivog razvoja.

Participacija javnosti se danas razumijeva kao jedan od temeljnih demokratskih procesa koji uključuje najširi spektar aktivnosti čiji je glavni cilj osigurati utjecaj javnosti na donošenje odluka. Povezana je s najnovijim pristupima tzv. planiranja "odozdo“ koji teže prepoznati i afirmirati autentične ljudske potrebe i prostorne aspiracije te uskladiti različite aktere i njihove, s prostorom povezane, interese (Harris, 2002.). U konačnici, participacija se danas afirmira kao jedna od važnijih metoda za postizanje i unaprjeđenje socijalno održivog razvoja (Mannberg, Wihlborg, 2008.).

\section{PREDMET, CILJ I METODA ISTRAŽIVANJA}

U ovoj analizi Sjeverozapadne Hrvatske fokus je na pet hrvatskih županija: Varaždinska županija, Međimurska županija, Koprivničko-križevačka, Krapinskozagorska i Zagrebačka županija. Cilj je utvrditi u kojoj mjeri je prostorni razvoj ovog područja obilježen dimenzijama socijalne i ekološke održivosti.

Na zadani cilj ovdje ćemo nastojati odgovoriti sagledavajući, uvažavajući i komparirajući dvije perspektive:

1. Normativnu perspektivu, koju možemo pratiti kroz analizu prostorno-planske dokumentacije i koja reflektira dominantne vrijednosti nekog društva i pruža viziju razvoja nekog prostora. Kao analitički okvir poslužila su 4 principa održivog razvoja (Waas i sur, 2011.): princip normationosti kojim se artikulira neki tip vrijednosti, princip jednakosti kojim se afirmiraju različiti aspekti jednakih 
šansi, princip integracije kojim se naglašava međusobna povezanost svih principa održivosti i princip dinamizma koji ističe važnost stalne prilagodbe promjenama, kao i potragu za odgovorima na nove okolišne situacije i rizike. Za svrhu ove analize izdvojen princip normativnosti. Sukladno tome, analiza se usmjerila na normativne akte - prostorne planove, a središnje je pitanje koliko su u prostornim planovima naglašene vrijednosti socijalne i ekološke održivosti. Analizirani su aktualni županijski prostorni planovi: Varaždinska županija (2000.), Međimurska županija (2001.), Krapinsko-zagorska županija (2002.), Koprivničko-križevačka županija (2001.), Zagrebačka županija (2015.).

2. Doživljajnu perspektivu, koju ćemo sagledati kroz stavove javnosti, stanovnika Sjeverozapadne Hrvatske o pitanjima povezanima s prostornim razvojem, a osobito o njihovoj participaciji u naznačenim procesima. U tu svrhu usporedit će se rezultati dva anketna istraživanja koja su sadržavala pitanja o uključenosti stanovništva $\mathrm{u}$ aktivnosti lokalne zajednice i koja govore o aspektu socijalne održivosti zajednice, te pitanja koja se odnose na dimenzije ekološke održivosti: stavove o prirodnom okolišu, njegovoj zaštiti i prihvatljivim izvorima energije. Istraživanja na koja se referiramo su: Pilarov barometar hrvatskog društva, jesen 2008. ( $\mathrm{n}=4000)$ i Pilarov barometar hrvatskog društva, proljeće 2014. $(\mathrm{n}=1000)$.

\section{REZULTATI I DISKUSIJA}

Za analizu županijskih planova određeni su indikatori socijalne i ekološke održivosti, sukladno preporukama Europske povelje planiranja (2013). Popis indikatora bio je polustrukturiran, otvoren, s mogućnošću upisa novih kako bi se ostavila mogućnost da se tekstovi planova interpretiraju vodeći računa o konceptima održivosti u najširem smislu.

Sadržaj planova analizirao se evidentirajući uključenost pojedinih indikatora, posebno za razinu ekološke održivosti, a posebno za socijalnu održivost.

Kako su županijski planovi normativni akti koji na regionalnoj (županijskoj) razini reflektiraju viziju prostornog razvoja nekog područja, bilo je za očekivati da će i u tom pogledu dati odgovore na pitanja o stanju u prostoru, ali i o onome što se projicira kao cilj tj. o poželjnom stanju u prostoru. Upravo u domeni ciljeva posebno se očekivala uključenost indikatora socijalne i ekološke održivosti, kao i jasno artikuliranih kriterija kojima bi se osigurala njihova afirmacija. 
Tablica 1. Rezultati analize županijskih planova.

\begin{tabular}{|l|c|l|c|}
\hline Socijalna održivost (indikatori) & & Ekološka održivost (indikatori) & \\
\hline Participacija javnosti & - & Zaštita prirodnih vrijednosti & $\sqrt{ }$ \\
\hline Informiranje javnosti & - & Zaštita krajolika & $\sqrt{ }$ \\
\hline Uključivanje lokalne zajednice & - & Zaštita prirodnih posebnosti & $\sqrt{ }$ \\
\hline Jačanje lokalne demokracije & - & Zbrinjavanje otpada & $\sqrt{ }$ \\
\hline Edukacija stanovništva (zdravlje) & $\sqrt{ }$ & Edukacija o prirodnim vrijednostima & $\sqrt{ }$ \\
\hline $\begin{array}{l}\text { Dostupnost (zdravstvo, socijalna } \\
\text { skrb) }\end{array}$ & $\sqrt{ }$ & Edukacija o zbrinjavanju otpada & $\sqrt{ }$ \\
\hline Dostupnost (osnovne škole) & $\sqrt{ }$ & Obnovljivi izvori energije & $\sqrt{ }$ \\
\hline Uključivanje lokalnih vlasti & $\sqrt{ }$ & \\
\hline Informiranje poduzetnika & $\sqrt{ }$ & \\
\hline Socijalna kohezija & - & & \\
\hline
\end{tabular}

Rezultati su prikazani u tablici 1 i pokazuju razliku već na razini implementiranosti ova dva koncepta. Indikatori ekološke održivosti prisutni su u županijskim planovima Sjeverozapadne Hrvatske pa se može zaključiti da se ovaj tip vrijednosti pretočio u normativne akte. No, s indikatorima socijalne održivosti situacija je nešto nepovoljnija. Rezultati pokazuju da se planovi zalažu za „klasične“ modernizacijske aspekte socijalnog razvoja koji se oslanjaju na standardnu socijalnu infrastrukturu i institucionalno su podržani. Riječ je o obrazovnim, zdravstvenim i socijalnim institucijama, pri čemu se ostaje na razini dostupnosti. Socijalni akteri čije se uključivanje nastoji osigurati normiranjem kroz plansku dokumentaciju su lokalne vlasti i poduzetnici, pa možemo reći da su u viziji županijskih planova upravo oni socijalni nositelji prostornog razdvoja koji se dominantno oslanja na planiranje „odozgo“. Indikatori koji proizlaze iz suvremenih koncepata planiranja "odozdo“, a odnose se na lokalnu zajednicu, osnaživanje lokalne demokracije, posebno kroz dobru komunikaciju i participaciju, te važnost socijalne kohezije - ostali su izvan horizonta analizirane dokumentacije. Slična analiza prostorno-planske dokumentacije obavljena na razini cijele Republike Hrvatske pokazala je da planovi Sjeverozapadne Hrvatske nisu izuzetak, već se uklapaju u opću sliku u kojoj na svim razinama nalazimo prisutne kriterije ekološke održivosti, dok su kriteriji socijalne održivosti zanemareni (Ursić, Mišetić, Mišetić, 2016.).

Ovakvi rezultati dodatno osnažuju motivaciju da se usporede sa stavovima lokalnog stanovništva i njihovim aspiracijama povezanima s uključivanjem u participativne procese $\mathrm{u}$ zajednici kao indikatorima socijalne dimenzije i sa njihovim stavovima o okolišu kao indikatorima ekološke dimenzije. 


\section{Socijalna dimenzija}

Premda većina ispitanika, očekivano, izjavljuje da nisu uključeni u društveni život svoje zajednice, rezultati prikazani u tablici 2 koji govore o participacijskim navikama stanovnika Sjeverozapadne Hrvatske. U odnosu hrvatski prosjek, oni su iznadprosječno uključeni u društveni život svoje zajednice. Svakako, nije zanemariv podatak da se oko $1 / 3$ građana tog područja povremeno ili redovito uključuje u neki vid društvene aktivnosti, dok je u slučaju Hrvatske u cjelini riječ $\mathrm{O}{ }^{1 / 4}$ takvih ispitanika.

Tablica 2. Na koji način ste uključeni u društveni život svoje zajednice (organizacija događanja, uređenje mjesta, civilne udruge i sl.)?

\begin{tabular}{|l|c|c|}
\hline & Sjeverozapadna Hrvatska & Republika Hrvatska \\
\hline Uopće nisam uključen. & 67,2 & 73,3 \\
\hline Povremeno sudjelujem u nekim aktivnostima. & 24 & 20,5 \\
\hline Redovito se uključujem u aktivnosti. & 6,1 & 4,4 \\
\hline Bez odgovora. & 2,7 & 1,8 \\
\hline
\end{tabular}

Izvor: Pilarov barometar hrvatskog društva, 2008. N=400

Dok je prethodno pitanje obuhvatilo najširi spektar društvenih događanja i ciljalo na općenitu, gotovo načelnu sklonost uključivanju, pitanje čiji su rezultati prikazani u tablici 3, na konkretniji način definira uključenost i s obzirom na svrhu djelovanja i s obzirom na vremensku aktualnost. I u ovom slučaju, u Sjeverozapadnoj Hrvatskoj veći je udio aktivnih građana nego u hrvatskom prosjeku. Ako se oba pitanja uzmu u obzir, osobito imajući na umu da je riječ o dva istraživanja provedena u intervalu od 6 godina, može se zaključiti da je nalaz o iznadprosječnoj participativnosti građana Sjeverozapadne Hrvatske u odnosu na cjelinu hrvatskog stanovništva - stabilan. Oko 1/3 stanovnika ovog područja, povremeno ili stalno participira u društvenim aktivnostima povezanima sa dobrobiti zajednice, što čini vrlo značajan socijalni potencijal za ozbiljnije uvođenje participativnih praksi kao alata planiranja i upravljanja.

Tablica 3. Jeste li u posljednjih godinu dana sudjelovali nekoj akciji koja je imala za cilj poboljšati uvjete življenja u vašem susjedstvu/lokalnoj zajednici?

\begin{tabular}{|l|c|c|}
\hline & Sjeverozapadna Hrvatska & Republika Hrvatska \\
\hline Nisam sudjelovao/la. & 68,4 & 72,7 \\
\hline Sudjelovao/la sam. & 29,1 & 25,9 \\
\hline Bez odgovora. & 2,6 & 1,4 \\
\hline
\end{tabular}

Izvor: Pilarov barometar hrvatskog društva, 2014. N=1000 
Kada se, pak, rezultati usporede s drugim istraživanjima koja su se bavila analizom civilnog društva, može se zaključiti da je manjinski udio ispitanika koji su sudjelovali u nekim akcijama za unaprjeđenje životnih uvjeta u lokalnoj zajednici sukladan još uvijek prisutnom nepovjerenju u mogućnost promjene i sklonosti da se odgovornost prenosi na "drugoga“, te relativno sporoj afirmaciji „mladog“ civilnog društva u Hrvatskoj (Matančević, Bežovan, 2013.).

\section{Ekološka dimenzija}

Općenito zadovoljstvo stanjem prirodnog okoliša u Hrvatskoj, za pretpostaviti je, u dobroj je mjeri određeno i zadovoljstvom stanja lokalnog okoliša. U odnosu na ostale dijelove Hrvatske, može se reći da je srednja ocjena zadovoljstva stanovnika Sjeverozapadne Hrvatske oko „zlatne sredine“ i najbliža hrvatskom prosjeku. Izuzmemo li, za ovu usporedbu, Grad Zagreb zbog specifičnosti metropolitanskog područja, ispitanici iz dviju prostornih cjelina iskazali su veće zadovoljstvo stanjem okoliša u Hrvatskoj (Slavonija i Istra i Primorje) od ispitanika iz Sjeverozapadne Hrvatske, a također, stanovnici iz dvije prostorne cjeline bili su nešto kritičniji u ocjeni kvalitete hrvatskog okoliša (Dalmacija i Središnja Hrvatska). No, pogledamo li vrijednosti ocjena koje su iskazane na ljestvici od 1 do 10, i koje se uglavnom kreću oko ocjene 6 , može se zaključiti da, po mišljenju ispitanika, ima još dosta razloga za poboljšanje stanja okoliša u Hrvatskoj.

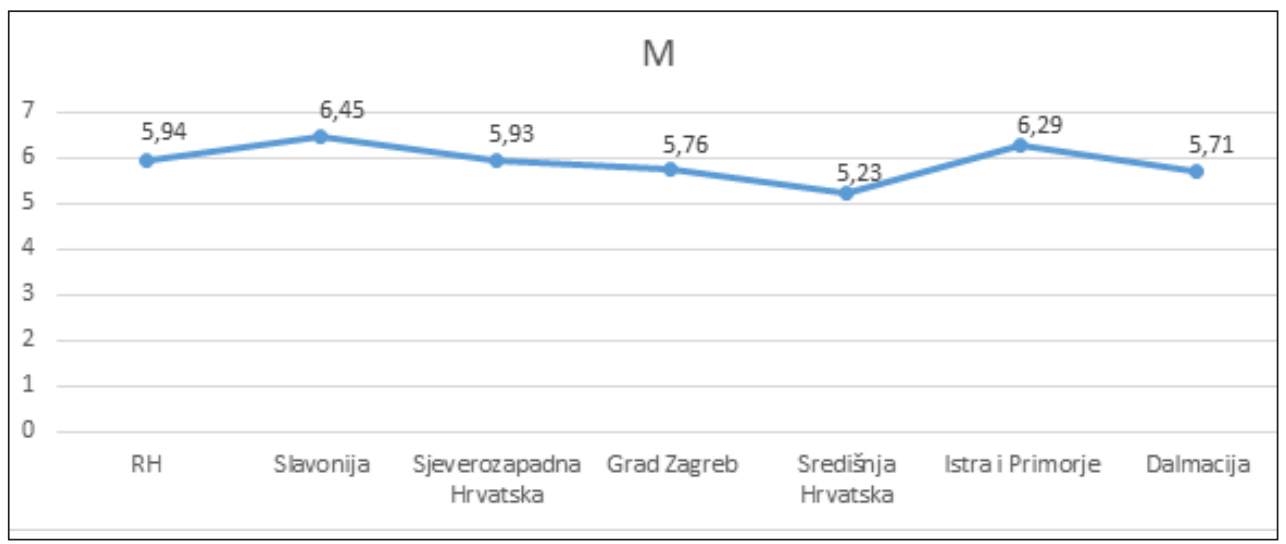

Slika 1. Koliko ste zadovoljni stanjem prirodnog okoliša u Hrvatskoj? (1-10) 
Nakon općenite ocjene zadovoljstva okolišem u Hrvatskoj, od pitanja o zadovoljstvu zaštitom lokalnog okoliša, očekuje se specifična informacija o uvjetima života ispitanika. No, rezultati na slici 2 ne pokazuju veće razlike od onih koje su već uočene na prethodnom pitanju. Time se potvrđuje pretpostavka da se prilikom ocjenjivanja stanja u Hrvatskoj, u velikoj mjeri imalo na umu lokalne uvjete, pa se odgovori na oba pitanja mogu čitati iz lokalne perspektive. Stoga, i u ovom slučaju vrijedi ponoviti zaključak o velikom prostoru za unapređenje životnog okoliša i podsjetiti na podatak da, primjerice, u Sjeverozapadnoj Hrvatskoj, 43\% ispitanika ne može reći da je zadovoljno u pogledu zaštite okoliša u mjestu u kojem živi.

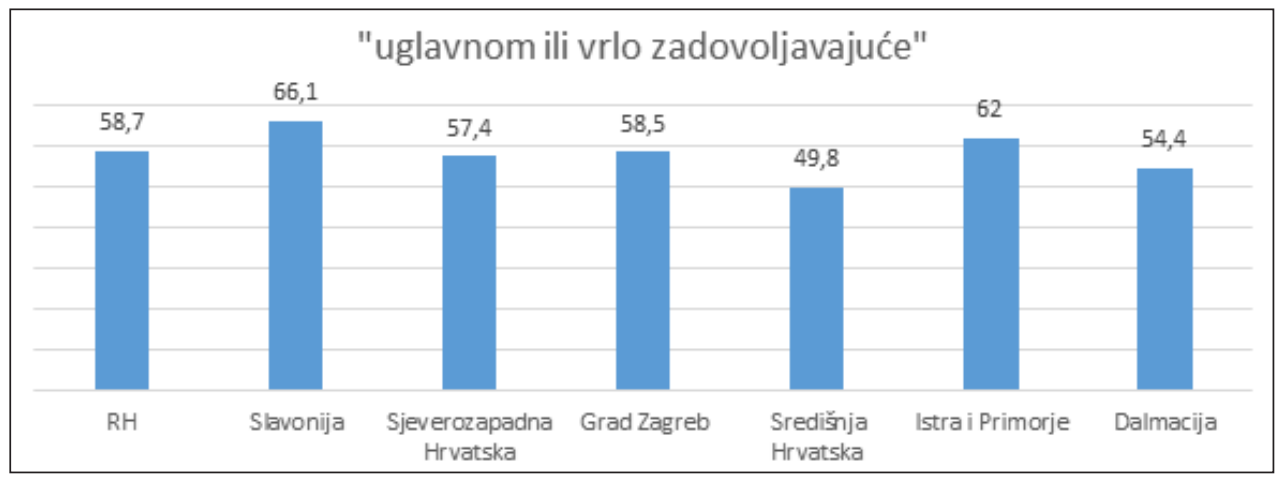

Slika 2. Kako ocjenjujete stanje u Vašem mjestu ili gradu u pogledu zaštite okoliša?

Izvor: Pilarov barometar hrvatskog društva, 2008. N=4000

Ipak, zanimljivo je ukazati na razliku u ocjenjivanju koja se pojavljuje $\mathrm{u}$ kategoriji najvećeg stupnja zadovoljstva (,vrlo zadovoljan“) gdje se vidi (Slika 3) da je relativno najveći udio ispitanika koji su bez zadrške iskazali zadovoljstvo - upravo iz područja Sjeverozapadne Hrvatske. Na ovoj razini istraživanja, ne bi bilo uputno upuštati se $\mathrm{u}$ daljnje interpretacije, no rezultat nije zanemariv i upućuje na potrebu detaljnijeg istraživanja ove teme, upravo na lokalnoj razini koja, može se pretpostaviti, kvalitetom zaštite u nekim mikro-sredinama generira ovako pozitivan stav. Takvi lokalni uspjesi mogu biti poticaj i primjer dobrog upravljanja i okolišnih politika. 


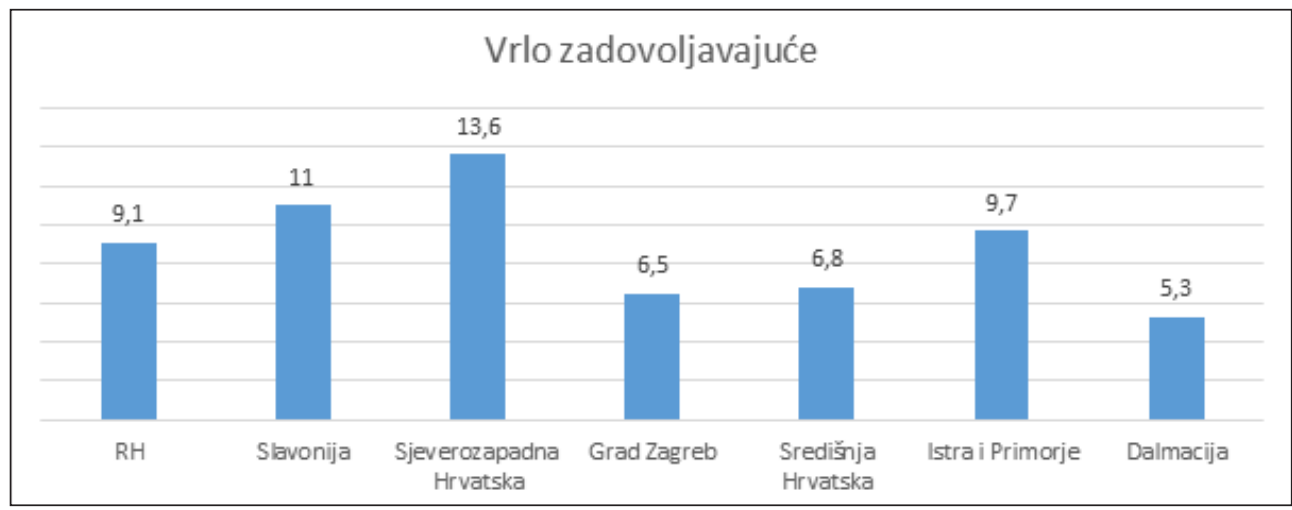

Slika 3. Kako ocjenjujete stanje u Vašem mjestu ili gradu u pogledu zaštite okoliša?

Odnos prema izgradnji pojedinih tipova elektroenergetskih postrojenja govori o ekološkoj svijesti ispitanika na najopćenitijoj razini. Predočena istraživanja pokazuju da su ekološke vrijednosti iskazane kroz ove stavove sukladne hrvatskom prosjeku.

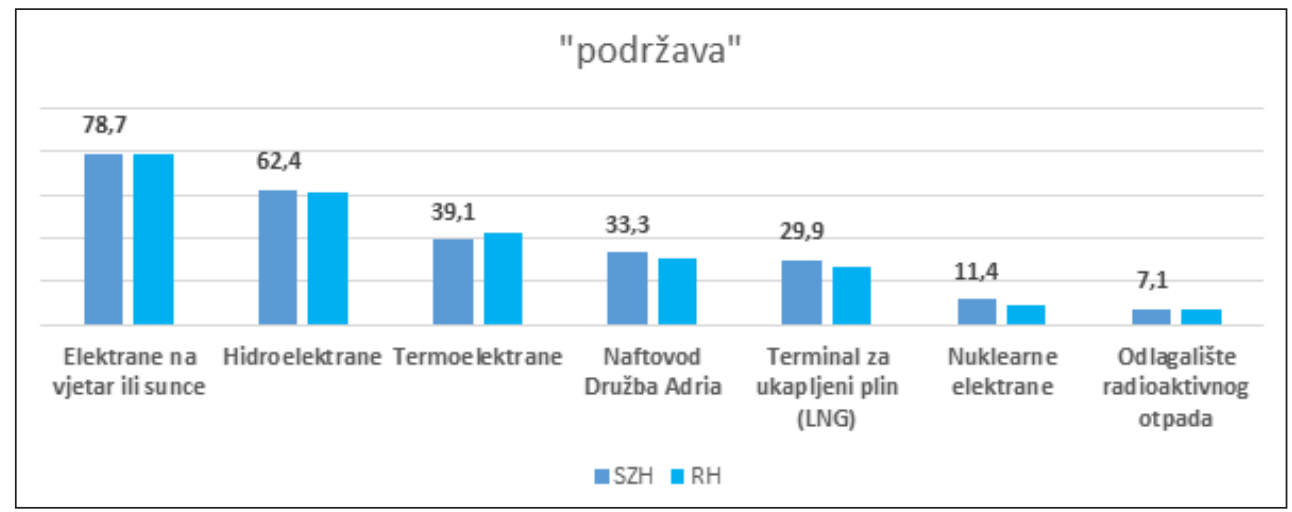

Slika 4. Kakav je vaš stav prema izgradnji pojedinih tipova elektroenergetskih postrojenja u Hrvatskoj? Izvor: Pilarov barometar hrvatskog društva, 2008. N=4000 


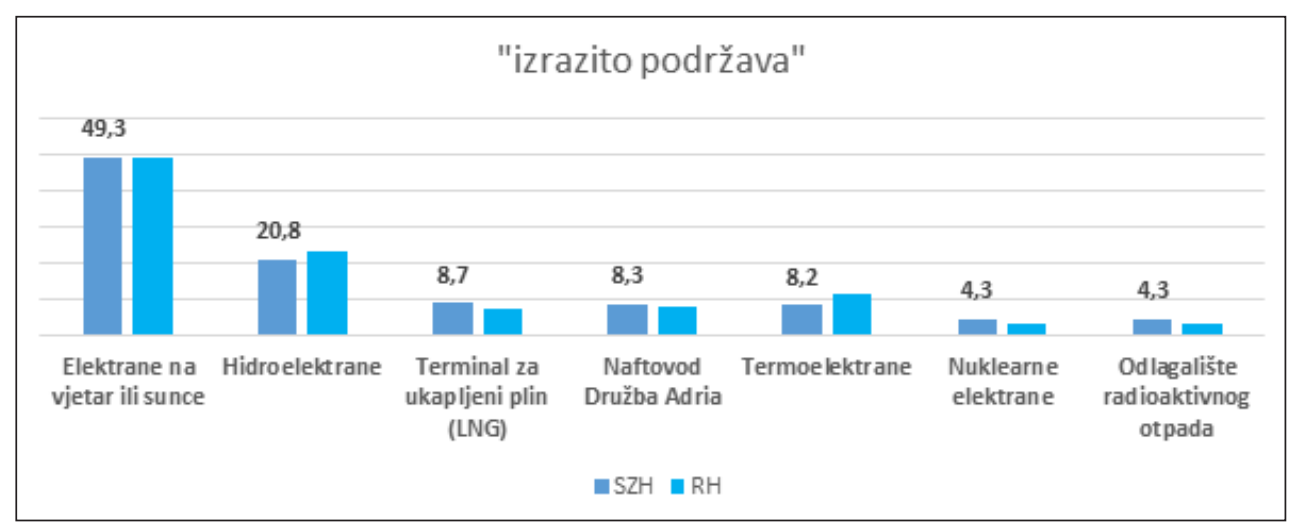

Slika 5. Kakav je vaš stav prema izgradnji pojedinih tipova elektroenergetskih postrojenja u Hrvatskoj?

Izvor: Pilarov barometar hrvatskog društva, 2008. N=4000

Očekivano, najprihvatljiviji oblici dobivanja energije su oni obnovljivi, koji trajno ne devastiraju okoliš, dok su najmanje prihvatljivi oni koji se doživljavaju s najviše rizika. Gotovo konsenzulano odbijanje rizičnih energetskih postrojenja snažan je indikator sindroma NIMBY (Not In My Back Yard) i NIABY (Not In Anyone's Back Yard) koji su karakteristični osobito za donošenje odluka o rizičnom otpadu (Buzjak, Vuk, Jakovčić, 2015.).

Unatoč sukladnom rangiranju prihvatljivih opcija, mogu se uočiti i neke manje razlike koje bi, za točniju interpretaciju trebalo dalje istraživati , a odnose se na relativno manju prihvaćenost termoelektrana kod ispitanika iz Sjeverozapadne Hrvatske u odnosu na državni prosjek i na također relativno bolju prihvaćenost nuklearnih elektrana i terminala za ukapljeni plin.

Kad je riječ o iskazanoj bezrezervnoj podršci (izrazito podržava), relativno veći udio ispitanika iz Sjeverozapadne Hrvatske prihvatio bi i odlagalište radioaktivnog otpada, dok bi manji udio od hrvatskog prosjeka nedvojbeno podržao hidroelektrane. I ovom slučaju, nalazi mogu poslužiti više kao upute za buduća, usmjerena istraživanja na lokalnoj populaciji. Svakako najkorisniji nalaz dobiven iz ovih istraživanja je jasno izražen kriterij ekološke održivosti kad je u pitanju prihvatljivost intervencija u okoliš gradnjom energetskih objekata. Davanje prednosti obnovljivim izvorima energije, kao i niska razina prihvaćenosti ekološki rizičnih intervencija u okoliš, stabilna je orijentacija potvrđena je i drugim istraživanjima u Hrvatskoj (Domac, Kufrin, Šegon, 2004., Mustapić, 2010). 


\section{ZAKLJUČAK}

Polazeći od ideje o prostoru Sjeverozapadne Hrvatske kao složenom fenomenu koji se razvija uključujući kulturne i socijalne dimenzije, u prvom redu vrijednosti i norme, te o uzajamnosti djelovanja društva i prostora u kojemu način života umnogome generira i prostorni razvoj nekog područja, analizirane su neki aspekti socijalnog okvira tog razvoja. U tu svrhu usporedili smo na koji način se principi ekološke i socijalne održivosti pojavljuju na normativnoj razini, u županijskim prostornim planovima, a te kako se pojavljuju u subjektivnoj perspektivi kroz stavove i ponašanje građana u svakodnevnom životu.

U pogledu uključenosti koncepta ekološke održivosti, stanje je zadovoljavajuće i na normativnoj i na doživljajnoj razini, što govori da je koncept ekološki prihvatljivog razvoja dobro prihvaćen i etabliran na svim razinama. No, s druge strane, u pogledu koncepta socijalne održivosti može se lako uočiti raskorak između normativne razine i svakodnevnih praksi. Takav zaključak proizlazi iz činjenice da je u pogledu uključenosti koncepta socijalne održivosti u ciljeve i kriterije razvoja, na normativnoj razini evidentan izostanak ideje o lokalnoj javnosti kao partneru u planiranju i provedbi prostornog razvoja u Sjeverozapadnoj Hrvatskoj. Principi suvremenog planiranja, poput participacije, informiranja, kapilarnog i neposrednog uključivanja svih društvenih sudionika nisu artikulirani kroz županijske prostorne planove, premda oni predstavljaju svojevrstan strateški dokument na regionalnoj razini. Nasuprot tome, navedeni procesi kao tendencije mogu se prepoznati u praksama svakodnevnog života o čemu svjedoči podatak da jedan značajan dio populacije (oko 30\%) participira u aktivnostima povezanima s razvojnim pitanjima. Ova grupa ispitanika koja je potvrdila da povremeno ili stalno djeluje za dobrobit lokalne zajednice predstavlja dobru osnovu za implementaciju novog tipa planiranja "odozdo“. Drugim riječima, oni su akteri preko kojih bi se u budućnosti mogao jače afirmirati koncept socijalno održivog upravljanja razvojem koji se oslanja na participaciju javnosti i jačanje lokalnih demokracija kao doprinos usklađenom razvoju društvenog i fizičkog okruženja i održivog socio-prostornog razvoja. Tome bi, svakako, doprinijela i temeljita istraživanja stavova $i$ aspiracija javnosti, ne samo o načelnim pitanjima održivog razvoja, već i o konkretnim lokalnim pitanjima i specifičnostima. U tom smislu, neki od ovih nalaza, osim što potvrđuju socijalni potencijal za participativni proces, mogu poslužiti kao hipoteze za buduća istraživanja i otvaranje dijaloga među socijalnim akterima. 


\section{LITERATURA}

1. M. BAKER, J. COAFFEE \& G. SHERRIFF (2007), Achieving successful participation in the new UK spatial planning system, Planning Practice and Research, 22(1), 79-93. DOI: 10.1080/02697450601173371

2. J. BARNETT, (2011), A Short Guide to 60 of the Newest Urbanisms. Planning Chicago, 77(4) 19-21.

3. L. BARRON, E. GAUNTLETT (2002), Housing and Sustainable Communities Indicators Project, Model of social sustainability, Stage 1 - Report, WACOSS.

4. N. BUZJAK, D. VUK, M. JAKOVČIĆ (2015.), The Issue of Landfill Location: Example of the

5. Tarno Site (Zagreb County, Croatia), Sociologija i prostor, 53 (2015) 202 (2): 117-137, DOI: 10.5673/sip.53.2.2

6. J. DOAK, G. PARKER, (2005), Networked space? The challenge of meaningful participation and the new spatial planning in England. Planning, Practice \& Research, 20(1), 23-40. DOI: 10.1080/02697450500261699

7. J. DOMAC, K. KUFRIN, V. ŠEGON (2004.), Obnovljivi izvori energije i energetska efikasnost, Stavovi i mišljenja stanovnika Zagreba i Rijeke, Socijalna ekologija, 13 (3-4), 347-364.

8. N. HARRIS (2002), Collaborative Planning: From Theoretical Foundations to Practice Forms, in Allmendinger, PH.; Tewdwr-Jones, M. (ed.) Planning Futures: New Directions for Planning Futures, Routledge, 21-44.

9. B. MAGAŠ, (2014.), Misli o arhitekturi - izabrani tekstovi, ur. A. Žunić, HAZU, Sveučilište u Zagrebu - Arhitektonski fakultet.

10. M. MANNBERG, E. WIHLBORG (2008), Communicative Planning - Friend or Foe? Obstacles and Opportunities for Implementing Sustainable Development Locally, Sustainable Development 16, 35-43, DOI: 10.1002/sd.325

11. J. MATANČEVIĆ, G. BEŽOVAN (2013.), Postaje li civilno društvo u Hrvatskoj čimbenikom društvenih promjena? Revija za socijalnu politiku,20 (1), 21-41.

12. A. MIŠETIĆ, G. M. MILETIĆ, S. URSIĆ (2012.), Vitalni gradovi, Institut društvenih znanosti Ivo Pilar, Zagreb.

13. M. MUSTAPIĆ (2010.), Odnos lokalne zajednice prema problemu odlaganja komunalnog otpada: Studija slučaja Makarsko primorje, Društvena istraživanja, 19,6 (110), 1055-1077.

14. D. SEFERAGIĆ (2008.), Akteri društvenih promjena u urbanom prostoru Hrvatske, Sociologija i prostor, 45 (3/4), 361-376. 
15. G. SIMMEL (2004.), Filozofija novca, IK Z. Stojanovića, Sremski Karlovci.

16. I. ROGIĆ (2003), Hrvatski nacionalni identitet i društvene elite. U: Baloban, S. (ur.) Hrvatski identitet u Europskoj uniji. Zagreb, Centar za promicanje socijalnog nauka Crkve, Glas Koncila.: 13-51.

17. The Charter of European Planning (2013), ECTP-CEU.

18. S. URSIĆ, R. MIŠETIĆ, A. MIŠETIĆ, (2016), New Perspectives on Sustainable Development of Second Homes in Croatia: Strategic Planning or Proliferation of Building?.Procedia - Social and Behavioral Sciences. 216; 80-86.

19. T. WAAS, J. HUGÉ, A. VERBRUGGEN, T. WRIGHT (2011), Sustainable Development: A Bird's Eye View. Sustainability 3(10), 1637-1661.

\section{Izvori}

http://barometar.pilar.hr (24.01.2017.)

http://barometar.pilar.hr (24.01.2017.)

\section{SAŽETAK \\ SOCIO-PROSTORNI ASPEKTI RAZVOJA SJEVEROZAPADNE HRVATSKE: IZMEĐU NORMIRANJA I PRAKSI}

Odnos društva i prostora karakteriziran je dinamikom načina života, vrijednosti, normi i običaja koji pokreću razvojne procese. U taj odnos kulture i prirode, čovjek unosi društvene vrijednosti kojima djeluje na prirodne resurse. Stoga, socio-prostorna analiza uključuje različite aspekte: ekološki, ambijentalni, ekonomski, socijalni, kulturni, a odgovornost za različite procese kojima se prostor transformira može se pripisati različitim socijalnim akterima, među kojima lokalna zajednica ima posebnu ulogu. Suvremene planerske prakse, na temelju koncepata komunikativnog planiranja, sve više naglašavaju primjerenost pristupa "odozdo" i važnost uključivanja lokalne zajednice u sve faze planiranja i implementacije prostornih strategija. Pri tome treba naglasiti konsenzus oko dvije vrijednosti: ekološke i socijalne održivosti. Na njima se, posljedično, oblikuju i kriteriji djelovanja. Ekološka održivost odnosi se na zaštitu cjeline života i životnih uvjeta. Socijalna održivost odnosi se na uvođenje participativnog procesa, postizanje uravnotežene zajednice, socijalne kohezije i zajednice koja je pravedna, raznovrsna, povezana i demokratična. Ovim se nastoji osigurati razvoj koji bi bio ekološki održiv i socijalno nekonfliktan. Analiza socio-prostornog razvoja Sjeverozapadne Hrvatske obuhvatila je pet županija:. Na prvoj razini analizirani su prostorni planovi pet županija s ciljem da se utvrdi u kojoj mjeri uključuju dimenzije socijalne i ekološke održivosti. Na drugoj strani razmatrani su rezultati dva istraživanja stavova lokalnog stanovništva u pogledu participacije u zajednici i stavova o okolišu i rizicima. 
Rezultati su pokazali da je koncept ekološke održivosti prihvaćen od strane lokalnog stanovništva i uključen u plansku dokumentaciju. S druge strane, koncept socijalne održivosti nije uključen u županijske planove. Lokalna javnost kao partner, participacija, informiranje i jačanje lokalne demokracije nije implementirana u prostorne planove. Anketna istraživanja pokazala su da su ekološke vrijednosti visoko su izražene i čine dobru vrijednosnu osnovu razvoja. U pogledu praksi socijalne održivosti, oko 30\% lokalnih stanovnika ovog prostora, u svakodnevnom životu sudjeluje u participativnom procesu. Rezultati upućuju na potrebu da se usklade normativna razina i svakodnevne prakse. Ideju o lokalnoj javnosti kao partneru u planiranju potrebno je afirmirati i na normativnoj razini, kroz prostorne planove, kako bi se ojačale demokratske procedure i stvorio okvir za efikasnije djelovanje civilnog sektora koji već i sada djeluje u lokalnim zajednicama.

Ključne riječi: Sjeverozapadna Hrvatska; lokalna zajednica; prostorno planiranje; participacija; socijalna održivost; ekološka održivost.

\section{SUMMARY}

\section{SOCIO-SPATIAL ASPECTS OF THE DEVELOPMENT IN NORTH-WEST CROATIA: BETWEEN NORMATIVE ACTS AND PRCTICES}

The relationship between society and space is characterized by lifestyle dynamics, values, norms and habits that drive development processes. In such interactions between culture and nature, people bring social values by which they affect natural resources. Therefore, sociospatial analyses include different aspects: ecological, ambient, economic, social, cultural, while responsibility for the different processes that transform space can be associated with different social actors. Among them, the local community has a special role. Contemporary planning practices based on communicative planning concepts, more than ever, emphasize the relevance of the bottom-up approach as well as the importance of including local community in every phase of planning and implementing spatial strategies. To this end, it should be stressed that there is a consensus on two values: ecological as well as social sustainability, which in turn, also shape criteria for acting. Ecological sustainability refers to protecting conditions for life and life as a whole. Social sustainability refers to implementing participation, achieving balanced community, social cohesion and a just, diverse, connected and democratic community. In this way, we should try to ensure ecologically sustainable and socially unambiguous development. The analysis of socio-spatial development in North-west Croatia includes five counties. In the first stage, spatial planning documents are analysed in order to answer the extent to which they include dimensions of social and ecological sustainability. At the next stage, results of the two surveys are discussed regarding locals' attitudes about community participation as well as environmental attitudes.

The results show that the concept of ecological sustainability is incorporated within planning documentation, and well-accepted by residents. On the other hand, the sociological sustainability concept is not included in the official planning documentation. The ideas of partnering with local community, and participating, informing and strengthening local 
democracy are not implemented in the spatial planning documents. Surveys have shown that high levels of ecological sustainability are a positive basis for development. Regarding social sustainability practices, approximately $30 \%$ of respondents have experience in participation processes in the local community. These results suggest a need to harmonise normative acts with life practices in the field of participation. The idea of the local public as partner in the planning procedures should be affirmed also at the normative level throughout spatial planning documents, in an attempt to improve democratic procedures and ensure the institutional framework for civil society actions that are already present in the local community.

Key Words: North-West Croatia; local community; space planning; participation; social sustainability; ecological sustainability. 